\title{
Kan leger ledes?
}

Det er mange ting i livet jeg lurer på, og mye vil jeg nok aldri få svar på. Ett av disse spørsmålene tenker jeg å stille til dere, men jeg vet ennå ikke hvilken kategori det tilhører. Spørsmålet er: Hvordan kan man lede helsearbeidere? Er det overhodet mulig?

Spørsmålet er ikke frekt ment. Det er uten tvil svært mange dyktige ledere i helsevesenet, og vi kan trolig smykke oss med det beste helsevesen i verden. Vi har høy levealder, høy livskvalitet og tilgang til helsetjenester for alle. I så måte kan man hevde at spørsmålet allerede er besvart.

Hvis man derimot definerer ledelse som kunsten å få alle til å dra i samme retning, er jeg ikke like sikker.

Det er heller ikke meningen å være arrogant. Det er jeg ikke i posisjon til. Politiet har fått svært mye kritikk de siste tre årene, mye med rette og mye knyttet til nettopp manglende ledelse. Spørsmålet er ment ærlig, ektefølt og ydmykt. Det er også viktig. Ikke bare for meg personlig. men også for det arbeidet politiet gjør.

Det er mange kontaktpunkter mellom helsevesenet og politiet. Vi løser mange av de samme problemene, vi møter mange av de samme menneskene, og vi er i mange situasjoner avhengig av hverandre for å løse våre oppgaver. Vi er begge viktige for et velfungerende samfunn, og vi driver begge med blant annet omsorg.

Samtidig er det lett å finne forskjellene. Vi bruker makt der dere bruker medisin. Der dere legger til grunn det pasienten forteller, er vi grunnleggende skeptiske.
Og våre taushetspliktsregler er ikke uten videre kompatible.

Det er også en del likhetstrekk knyttet til ledelsesutfordringer. Vi leverer begge tjenester som er avhengig av beslutningsstyrke i ytterste ledd. De valg helsepersonell og politifolk tar mange ganger hver dag, kan ikke sentraliseres. Publikum er avhengig av individuell vurdering av problemene de er midt oppi for å kunne få god hjelp.

Vi har begge regler, rutiner, prosedyrer og vaner. Mange er gitt av overordnet myndighet, mange bygger på erfaring, mye på forskning og en god del på følelser. Felles for begge etater er at disse i ganske stor grad følges, ofte endres og ikke rent sjelden gir grobunn for intense diskusjoner. Vi preges nemlig begge av energiske fagfolk som kjemper for sine egne faglige standpunkter. Dette er positivt og skaper utvikling. Det er også utfordrende for den som skal lede virksomheten.

Vi er begge underlagt politisk styring, der vanskelige spørsmål sjelden besvares og der forventningene i praksis ikke kan imøtegås. En debatt om bioteknologi, tilregnelighet, reservasjon eller straffenivå er vanskelig i spenningsfeltet mellom morgenens avisforsider og kveldens TVdebatter. Vi prøver selvfølgelig det vi kan og er innforstått med at det nok ikke finnes noe bedre alternativ.

Spørsmålet til dere er altså viktig for meg. For hvis noen har svaret, er det viktig for den videre utvikling også av politiet. Et av de forhold som får meg til å lure, er hvordan helsevesenet følger opp familievoldssaker som involverer barn.

Det er uttrykkelig dokumentert at barn som lever med vold, har en enorm risiko for en rekke sosiale og helsemessige utfordringer. At de også synes å være utsatt for å bli kriminelle, gjør ikke nødvendigvis inntrykk på helsearbeidere. Men at de påføres fysisk og psykisk skade ved å utsettes for vold både direkte og indirekte, er jo midt i kjernen av hva helsearbeidere skal være opptatt av.

Hvorfor avdekkes det da så lite? I saker der vedvarende vold kommer opp, ser vi nesten alltid at det har vært flere muligheter til å avdekke det som foregår, også av leger og helsearbeidere.

Unnfallenheten synes å gå helt til topps. Når det kommer nye handlingsplaner mot familievold, er det justismyndighetene som pålegges konkrete tiltak, mens det kan synes som om helsemyndighetene bare deltar på pressekonferansen.

Vi vet nå hvor farlig dette er, vi vet hvilke helsemessige konsekvenser dette har, vi vet en del om hva vi skal se etter, og vi har rutiner for hva vi skal gjøre når vi ser det. Hvorfor avdekkes det da så lite?

For meg illustrerer det ledelsesparadokset. Vi er avhengig av at de ansatte er høykompetente. At de kan treffe individuelle beslutninger basert på faglig skjønn og en konkret vurdering av den utfordringen de står overfor. Vi er samtidig avhengig av at de følger rutiner og er i stand til å tilpasse seg ny kunnskap.

Hvordan utvikler man en organisasjon til å bli kompetent, individuell og lydig på én gang? Hvis noen har svaret på hvordan det skal gjøres, så ring meg.

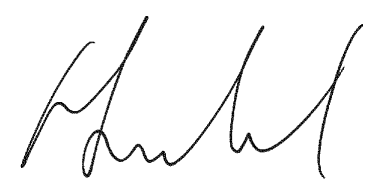

